\title{
Waste Recycling, An Example Of Refuse Collecting As A Means of Livelihood In The Informal Sector Of Nsukka Urban Area, Enugu State, Nigeria.
}

\author{
S. Okonkwo Ogbu \\ Department of Geography and Meteorology, \\ Faculty of Environmental Sciences. \\ Enugu State University of Science and Technology (ESUT), Enugu. \\ J. C. Ajadike \\ Department of Geography and Meteorology, \\ Faculty of Environmental Sciences. \\ Enugu State University of Science and Technology (ESUT), Enugu. \\ Hillary Ndubuisi Ugwu \\ Department of Geography and Meteorology, \\ Faculty of Environmental Sciences. \\ Enugu State University of Science and Technology (ESUT), Enugu.
}

\begin{abstract}
This study explored how picking waste materials has aided sustenance in the livelihood of scavengers, an informal sector in Nsukka urban area of Enugu State, Nigeria. It aimed at identifying the demographic and socioeconomic characteristics of scavengers as well as the type and uses of collected waste materials. Survey research design was adopted in this study. A total of 411 scavengers (45.7\%) were sampled out of the available 900 scavengers in the four administrative units of Nsukka Urban area as follows; Ihe/Owerre (165), Obukpa (82), Nru (82) and Mpkunano (82). The data were collected using the instrument of questionnaire, oral interview, and field observation. Data obtained were analyzed using percentage and rank methods, graphs (especially bar and pie graphs), and KrusKal-Wallis statistical techniques. The socioeconomic features of the respondents identified were; gender (males, $88.8 \%$ and females $11.2 \%$ ); age (525years (19.4\%), 26-45years $(47.2 \%)$, and above 46 years $(33.4 \%)$ ); education (nonformal education (13.4\%), FSLC (46.6\%), GCE/SSCE (36.4\%), OND (2.0\%), HND (1.0\%) and B Sc/B.A. (0.6\%)); and Marital status (single (64.4\%), and married (6.6\%), widowed $(17.8 \%)$ and divorced $(11.2 \%))$. The results obtained reveal that useful materials collected in the area originate in descending order from metals (54.6\%), glass $(23.8 \%)$, Plastics $(10.4 \%)$, foods $(6.2 \%)$, and papers $(5.0 \%)$. These materials are found to be useful in two major areas of sales as source of income (78.2\%), and for domestic purposes $(21.8 \%)$. The ranges of income derived from scavenging in the area vary from below $\$ 2,000.00$ to above $\$ 20,000.00$ per month with $\$ 10,001.00-\$ 20$, $000.00(39.2 \%)$ dominating other income levels. From these results, it is recommended that scavenging business should be encouraged by government and industrialist through the establishment of industrial activities that recycle and use recycled materials as input materials in the study area.
\end{abstract}

Key Words: Waste materials, recycling, livelihood, scavengers, informal sector.

\section{INTRODUCTION}

Wastes are not only environmental problems, but also economic losses and to make matters worse, the amount of wastes being generated everyday globally is on the increase. A vivid example of man's influence on the environment according to Medina (2007) is poisoning of the 
soil, surface and underground waters, and the atmosphere with floods of wastes that threaten to take over the earth. Ecosystems of our planet are no longer capable of digesting the everincreasing volumes of wastes and new synthetic chemicals alien to nature. Such ecosystems like the marine ecosystem such as fishes, sea weeds, water, octopus, wales, and the terrestrial ones such as plants, cows, goats, chicken, and humans are adversely affected by wastes. The addition of chemical wastes from pesticides and herbicides in agriculture which are distributed to both land and water bodies by run-offs has led to a significant increase in the contamination of land and water bodies (Espinoza, 2014).

However, as wastes are detrimental to man, millions of people worldwide make their living by collecting, sorting, recycling, selling, and using what others have thrown away as wastes. Waste recycling has been a part of the society since $8^{\text {th }}$ century (Smithsonia, 2016), but has just from the beginning of the $19^{\text {th }}$ century been given attention by researchers with regards to how people have made money from selling waste materials. To Mustapher (2011), waste recycling has been a means of livelihood in the informal sector which occurs at both household and industrial levels, and it takes many different forms. Sometimes, it is merely reusing a waste product for a different purpose. Other times, it involves using waste products as raw material for the production of another new item of value. Again, they are collected and prepared for sales to make money or as the need be.

Scavenging is a common income generation activity mostly carried out by disadvantaged individuals like the uneducated or the unemployed and it is still illegal in many cities in Africa like Nigeria, South Africa, Libya, Asia (especially India, Saudi Arabia, Oman), and Latin America as in Brazil, Colombia, and Bolivia (Smithsonia, 2016).

The service of cleaning cities rendered by scavengers as they are commonly called has been largely undermined due to the undignified nature of their works. There has also been scarcity of information on the amount and types of wastes collected. Again, wastes collections provide crucial earnings for the families of those engaged in it, but there is dearth of information on the extent to which refuse collection has provided incomes to people in the informal sector. This is the reason for this study in order to determine the types of waste materials collected by scavengers, and the importance of scavenging as a means of livelihood and sustenance to people in the informal sector of Nsukka Urban area of Enugu state, Nigeria.

\section{LITERATURE REVIEW}

The review involved definitions of concepts, types/classes of wastes, and benefits derived from wastes collecting. Waste according to Ekwueme and Achikanu (2002), and Joana (2008) is a used, unwanted or discarded materials that can be solid, liquid or gaseous material, and obtained directly or indirectly from human activities. To Uchegbu (2014), waste is any unavoidable material resulting from domestic activities or industrial operations for which there is no economic demand and which must be disposed off. Odocha (2002) further explained that wastes are those materials over which we have control in terms of their production, disposal or discharge. They are non-liquid and non-gaseous residues of manufacturing, construction, cooking, recreation, agriculture and other activities that use and discard materials (Sidwell, 2016). Therefore, wastes generally do not just imply worthless substance, but represent a more subjective case because a material that is regarded as waste by an individual or industry may be useful to another individual or as a raw material to another industry.

Recycling is the treatment of materials or substances that have been used or that are not useful so that they can be useful again (Joana, 2008). Consolidating this view, Diaz (2008) saw 
recycling as a change of state, process and composition of substances or material from a useless or less useful to a useful or more useful state. This is the reason for Seligoretal (2002) to show that recycling is a process of reusing renewable resources in an effort to maximize their value, reduce waste, and minimize environmental disturbances. This will reduce the amount of wastes that are sent to land-fills or incinerators and increase the quantity of items available to scavengers. It will also help industrialists to obtain maximum value from raw materials as well as relieve the pressure on our dwindling natural sources of industrial raw materials (Paulson, 2017).

Joana (2010) defined scavenging as a human activity that involves searching through waste for things that can be used. The individuals engaged in this activity are generally known as waste pickers, refuse collectors or scavengers (Singh, 2015). To Medina (2007), scavenging is a labour process that initially involves the collection and then the sale and processing of recoverable materials. According to Loan (2002), Scavengers are not concerned with waste management, but are only interested in those waste materials which are useful to them or which they can sell to make money and their relationship with wastes is as a source of resource (s) i.e. they collect only those materials for which their market or use exist. This amongst other reasons such as the nature of the job, the low income earning and the health risks associated with scavenging is why scavenging is often looked upon as an activity undertaken only by destitute and those who are unable to secure a job as opined by Diaz (2008) and Nzeadibe, (2009).

\section{Classes of Wastes.}

Wastes come in different forms, sources, compositions and may include; metals, foods, plastics glasses, and paper waste materials (Ugwuishiwu, Nwodo, and Echiegu, 2016).

Metal wastes: These are commonly referred to as scrap metals which consist of materials left over from product manufacturing and consumption, such as the iron and steel parts of vehicles, building supplies, office and domestic materials. Scrap metals have higher monetary value than other wastes. Non- ferrous metallic materials such as aluminum, magnesium, copper, brass, tin and Zinc also recovered for recycling are included in this class. According to the International Resource Panel's Metal Stocks in Society report (2004), scrap metals recovered for recycling can be typified into; heavy melting steel, old car bodies, cast iron, pressing steel, reinforcing bars or mesh, turnings, manganese steel, and rails.

Food wastes: Foods that are discarded or lost uneaten are referred to as food wastes which occur at all the stages of production, processing, retailing, and consumption. They also occur at all stages of the food supply chain or value chain. In low-income countries such as Nepal, Sudan, Syria, Haiti, Laos and Nigeria, most loss occur during production, while in developed countries such as Germany, United States, Britain, Sweden, Switzerland, Russia, France and Denmark much food, about 100 kilograms $(220 \mathrm{lb})$ per person per year is wasted at the consumption stage (US Department of Agriculture (USDA), 2015). Lost food may go to landfills, be put back into the food supply chain, or be put to other nonfood productive uses. All foods can go to waste but cooked foods, fruits and vegetables are more prone to waste because they spoil at the slightest mismanagement (McGrew and Moore, 2000).

Plastic wastes: These are wastes from any of numerous organic, synthetic or processed materials that are mostly thermoplastic or thermosetting polymers of high molecular weight and that can be made into objects, films, or filaments. These wastes (synthetic or semi synthetic, organic, amorphous, solid materials) are derived from oil and natural gas (Jersey, 
2018), that unlike metal and food wastes, take much longer time to decompose in the soil. Examples of commonly discarded plastic materials are used nylon bags, vehicle tubes and tires, plastic bottles for drinks such as water and soft drinks, broken plastic chairs and tables, worn out rubber footwear, plastic plates, spoons, jugs and cups used in homes and offices.

Glass wastes: Glass materials as noted by Standing (2000) can easily become wastes due to their highly fragile nature. Once broken, they cannot be used again but can only be recovered for recycling. Majority of glass wastes are derived from glass bottles, automobile parts, chairs and tables, home appliances such as televisions and utensils (cups, jugs, plates and food kitchen shelves), mobile phones, windows, and doors.

Paper wastes: Papers are composed of cellulose materials obtained from wood pulp. Paper wastes are generated in large quantities from old newspapers and notebooks, toilet tissue papers, papers used for printing of documents especially in offices and schools as well as those used in packaging of goods such as cartoons (Diaz, 2008). Paper wastes do not pose a serious pollution risk according to Asim (2012) because of the ease with which paper wastes decompose and join the natural cycles in the soil even without burning them.

\section{Waste Recycling.}

Waste recycling is currently the least pursued method of waste management not withstanding that it is potentially the most effective waste management method (Standing, 2000). Waste recycling is a process of converting waste materials into new products to prevent wastes of potentially useful materials. Sometimes, it is to supplement the consumption of fresh raw materials, reduce energy usage, and reduce air pollution from incineration and water pollution from land filling. Other times, it is to reduce the need for conventional waste disposal methods and lower greenhouse gas emissions. The materials that can be recycled include glass, aluminum, water sachets, yoghurt wrappers, popcorn wrapper, bread wrappers, cellophane bags, plastic water bottles, metal scraps, different kinds of paper, electronics (computers, cellular phones, keyboards, batteries), textile, wood, wire, cables, plastic products, rubber. Apart from these industrially recyclable materials, domestic ones such as leaves, food leftovers, twigs and other garden wastes can be decomposed by worms and converted into fertilizers.

In fact, the concept of recycling is increasingly gaining popularity as many urban agencies now adopt recycling programs (Madu, 2004). Madu (2004) in one of his reports to the Environmental protection Agency (EPA) on "The Need for Recycling" said that recycling contributes significantly to the reduction in the amount of waste materials sent to landfills and incinerators.

In many countries such as Norway, United Kingdom, United States of America, Russia, China, Switzerland, Australia, etc authorities provide industries and households with labeled bins to facilitate materials collection and sorting.

\section{Benefits from collected Waste Materials.}

The following are the benefits derivable from making waste recycling an integral part of waste management strategies in a nation. They are; protection of the environment, conservation of natural resources, creates jobs, saves energy, and reduces health risks associated with conventional waste disposal methods.

a. Protection of the Environment: Recycling protects the environment by removing and putting to good use those materials that would have been burnt or sent to landfills where they still constitute any or all of air, land or water pollutant. For example, in Central Texas, United 
States natural gas which is a by-product of oil exploration instead of being flared into the atmosphere where it constitutes atmospheric pollutant is converted and used as cooking gas, thus, protecting the atmospheric environment for the hazards of natural gas flaring.

b. Conservation of natural resources: Recycling of wastes means that we do not have to depend always on natural raw materials which helps to relieve the already too much pressure on nature supplied raw materials (Cooper, 2011). This is vividly illustrated in Nigeria where water sachets are used as raw materials for the production of thermoplastic materials such as chairs, buckets, plates, and hence, conserve coal, oil and natural gas which are the nature supplied raw materials for plastic production (Madu, 2004).

c. Scavenging creates jobs: People are employed to collect, sort, transport, sale and work in recycling industrial plants, while others also get jobs with businesses that work with these recycling units (UN Habitat, 2010). Un Habitat (2010) further explained that in some countries such as Haiti, Nepal, Syria, Laos, Libya, Sierra Leone, Cambodia, scavengers constitute the bulk of people whose jobs are sustained by recycling industries.

d. Scavenging saves energy: Using useful materials in the manufacturing processes involves considerably less energy than that required to obtain fresh raw materials. For example, the cost of using rusted iron as recycled raw material is reasonably less than the cost of smelting fresh iron from its ore even if quality of the material obtained is considered (Jersey, 2018).

e Recycling reduces health risks associated with conventional waste disposal methods. This is true because if waste materials are recycled, they are no longer available to be sent to landfills or burnt where they produce particulate matter that cause heart, skin, respiratory and emphysema diseases upon exposure as in the case of the oil fields in parts of Nigeria, Algeria, Syria, Ukraine (World Health Organization(WHO), (2013).

\section{The Relationship between Scavenging and Recycling.}

Birkberck (2000) who analyzed the link that exist between scavenging and recycling discovered that the major link is in the supply of raw materials and the provision of market i.e. recycling industries depend on the scavengers to purchase their goods. Furthermore, Asim (2012) discovered that scavengers in their supply of secondary materials to recycling industries also reduce the amount of wastes and save waste management authorities the huge expenditures on sweeping, transportation and disposal of wastes, thereby giving the government good reasons to encourage and support recycling industries.

\section{THE STUDY AREA}

Nsukka urban area is located in Nsukka Local Government Area of Enugu state (Fig. 1), SouthEast of Nigeria. An urban area refers to an area with a large number of people residing in it, an area that has been significantly developed, an area where the distance between buildings is very small, a non-agricultural based area, an area with the availability of basic requirements, and lots of opportunity for employment, presence of local authority, and quality of population (Deuskar, 2015, and Sociology Group, 2017). It lies within latitudes 6024' and $7^{0} 23^{\prime}$ north of the equator, and longitudes $6^{0} 51^{\prime}$ and $7^{0} 32^{\prime}$ east of the prime meridian and covers a total surface area of approximately 47.5 square kilometers. Nsukka urban area is bounded in the east by Eha-Alumona and Orba communities, in the west by Edem-ani community, in the north by Obukpa community, and in the south by Obimo community (Fig.2). The area is 423 meters above mean sea level, and it is surrounded by hills particularly at the southern part around Nguru area. The central parts are made up of relatively undulating low lands with small hills 
that have been greatly lowered by human activities especially at Ugwu-Awarawa towards Alouno. Nsukka Urban area has a total population of 417, 700 persons (2018 population projected from 2006 census) and a population density of 8,794 persons per square kilometer. The drainage system of the study area is characterized by flat bottom dry valleys which are the former normal river valleys that later dried up by infiltrations into the false bedded sandstones. Some streams in the area are Asho stream in Onuiyi, Ajie stream in Odenigbo, lyi Nsukka in Echara. Throughout the area, temperature remains relatively high with a daily mean of $21.0^{\circ} \mathrm{C}$. Annual rainfall varies from $986 \mathrm{~mm}$ to $2,098 \mathrm{~mm}$ due to its location on the fringe of a monsoon climate (Nigeria Meteorological Agency (NIMET), 2014). The climate is largely influenced by the North-east and South-West trade winds. Relative humidity is highest in the morning usually between $90 \%$ and $95 \%$ and reduces as temperature rises. 
Fig. 3.1:Nsukka Urban Area in Enugu State.

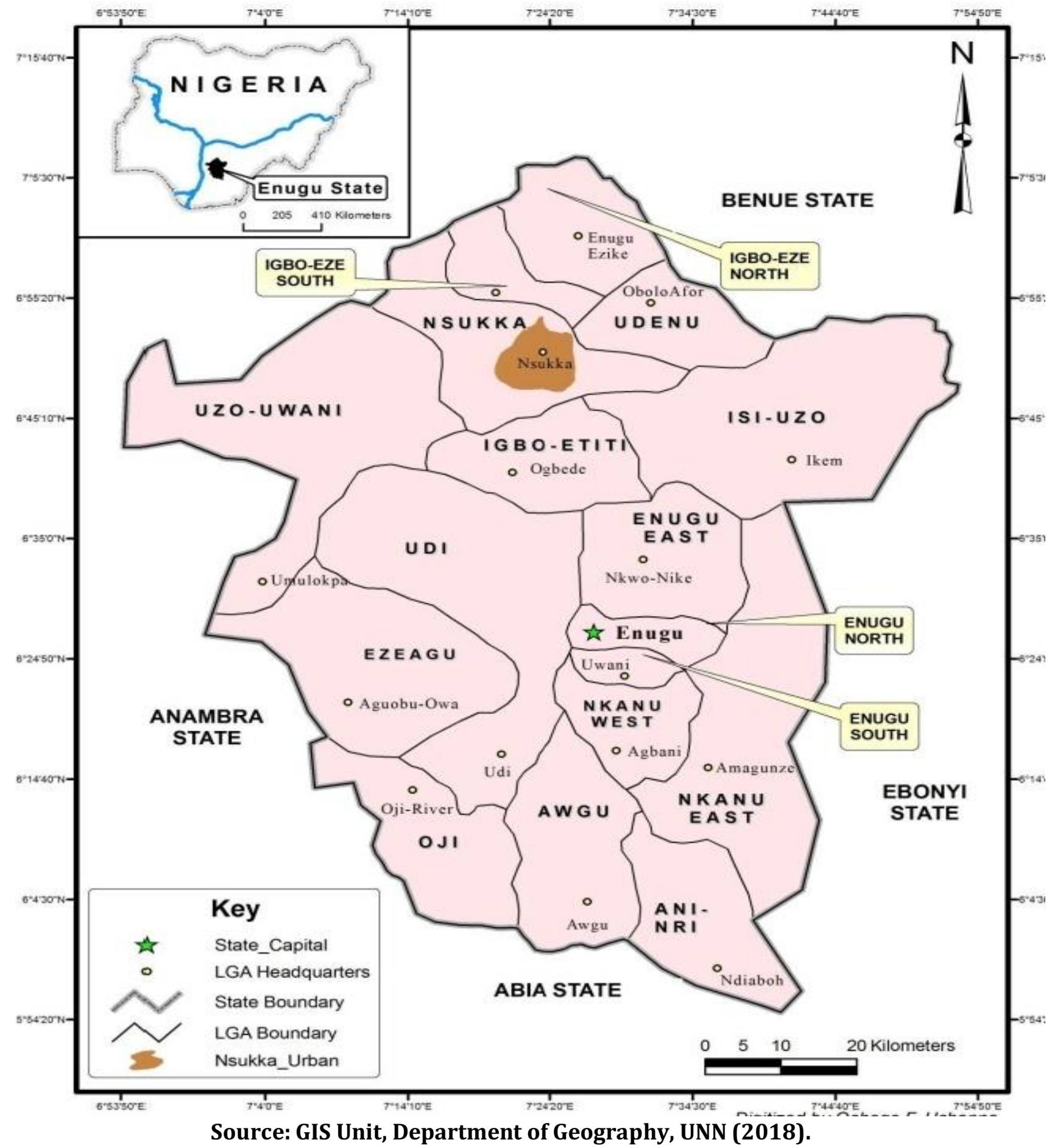


Fig. 2 Administrative units in Nsukka Urban Area

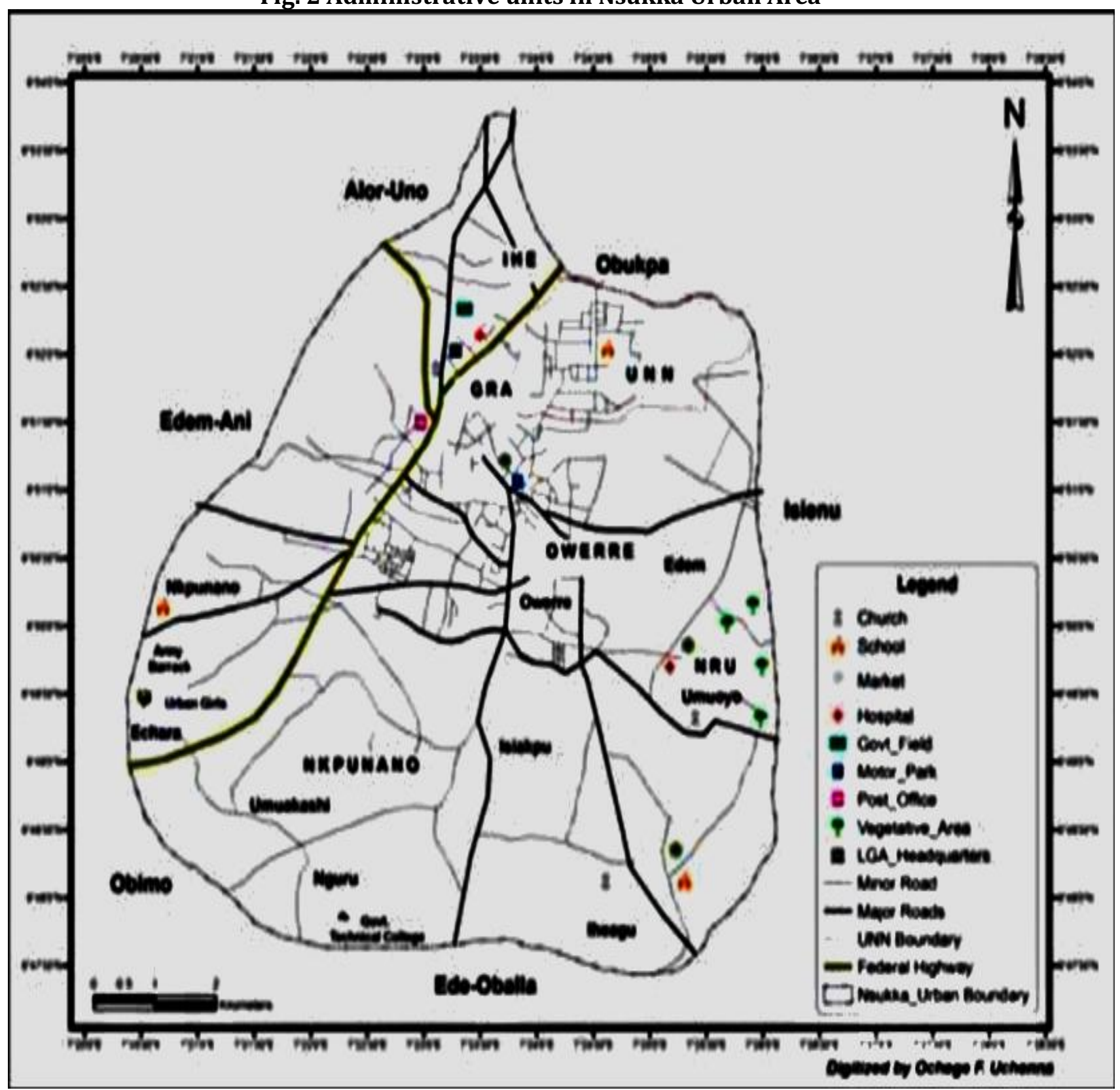

Source: GIS Unit, Department of Geography, UNN (2018).

There are also the ferrallitic soils called red earth found on plateaux at Ugwu-Awarawa and Ikenga areas, and the hydromorphic soils of the flood plains (Amah, 2006).

The vegetation of Nsukka urban area was dominated by the structural forms of broad-leaved trees such as Iroko, Mango, palm trees found at Agu Nru and Onuiyi area and substantial grass undergrowth such as spear grass, elephant grass, and thorn weeds found at Odoru, Ikwuoka and at Edem Ani area. Human activities have caused the destruction of the original forest cover such that the prevailing types of vegetation now are known as derived savanna. The predominant economic activity in Nsukka urban area is subsistence farming along with small scale business enterprises. Such crops cultivated include cassava, maize, okra, yam, pepper, tomato, vegetables, and cocoyam. Some individuals have gone into commercial agriculture as can be seen from the pepper and garden egg farms at Ubom, Agu-Ihe, Uwalu-Ugwu and Obelibe, and Nguru (Agu, 2010). Mining laterites and fine sand occurs or are undertaken at Umakashi, Nru, Nguru (Agu, 2010). Also, there are scavengers who collect waste materials to sell to junk shops and industries found at many places in the area. 


\section{RESEARCH METHODOLOGY}

The methods and procedures adopted in this research work involve research design, population of the study, sources of data, sampling techniques, sample frame and size, methods of data collection and analyses. Survey research design was adopted in this study because it was very difficult for the researchers to reach all the waste pickers in Nsukka Urban area given the limited resources of time and money available. In other words, samples were drawn from where relevant information about the entire population was deduced. Data were obtained from informal sector scavengers as well as owners and employees of junk shops in the area.

In this study, the quota sampling method was used to have a proportional representation from different interest groups. This research adopted the four principal administrative units that make up Nsukka Urban Area and samples were assigned to each administrative unit based on the population of scavengers within it. The four administrative units have 900 Scavengers who are distributed as follows; Ihe/Owerre (300), Obukpa (193), Mkpunano (211), and Nru (225). The samples of $165,82,82$, and 82 were respectively drawn from the four administrative units using simple random sampling technique. The equal number of respondents sampled in Mkpunano, Obukpa, and Nru was due to little variations in the number of respondents among these three administrative units. Therefore, 411 respondents or $45.7 \%$ of the sample frame were involved in this study.

In this study, questionnaire, oral interview, and field observations were the instrument used. Both structured and unstructured questions and interview were adopted in order to identify the types of waste materials collected, their uses, and the monthly income obtained from the sales of the useful materials collected. Interviews and field observations supplemented questionnaire and the results obtained were merged with those from the questionnaire responses. The researchers adopted the method of descriptive statistics, graphs such as pie and bar graphs, and percentage ratio for the analyses of data obtained from the field.

Also, KrusKal-Wallis statistical technique was adopted in data analyses because it is best suited for assessing frequencies in the spatial variations of the distribution of phenomena or materials as indicated by Sidwell, (2016). Its fomular is;

$$
H=\frac{12}{n(n+1)} \sum_{i=1}^{k} \frac{R_{i}^{2}}{n_{i}}-3(n+1)
$$

Where

$\mathrm{H}=$ KrusKal-Wallis test statistics,

$\mathrm{K}=$ Number of sampled groups,

$\mathrm{n}=$ Total number of observations from independent samples,

$\mathrm{Ri}=$ Rank sum of each sample,

$\mathrm{ni}=$ Number of observations for each waste type

\section{RESULTS AND DISCUSSIONS}

Copies of questionnaire distributed were 500 and the number returned were 411 (82.2\%), and 89 copies $(17.8 \%)$ were not returned for the fact that scavenging is not the only business for our respondents and as such they were not always reached on demand.

The variables of the socioeconomic status of the respondents verified are gender, age, education and marital status. The result shows that more males than females are involved in 
wastes scavenging in the study area. This is because out of 411 respondents, $88.8 \%$ that represent 365 scavengers are males, while 46 or $11.2 \%$ of the respondents are females. This is because the activity of scavenging requires movement from one place to another in addition to the heavy and bulky load one has to carry. The energy requirements of these are more spent by males as well as youths than females. These trends are the same as those found out by Nzeadibe, (2009) in Nsuka region, Chukwu (2016) in Enugu North Local Government Area, Nigeria, Mustapher (2011) in Lagos state where more males than females are involved in picking of useful waste materials. But this differs from the result obtained by Schreiber (2018) who found that in Nepal, more women than males were engaged in the scavenging activities.

The age distribution of scavengers ranges from 5 to 56 years in which 24 respondents $(6.0 \%)$ are between 5 and 15 years, 136 (33.0\%) are within 16 and 35 years, 114 (27.0\%) fall into 3645 years, 68 or $16.4 \%$ of them are within $46-55$ years, and in above 56 years of age are 69 that represent $16.7 \%$ respondents. Thus, scavengers in the study area are mainly young adults that comprise 387 respondents (94.0\%) and found between 16 - 56 years.

The educational qualifications of scavengers in Nsukka urban area are none formal education, FSLC, GCE, OND, HND, and B Sc/B A. Each of them obtained response score of 55 (13.4\%), 192 (46.7\%), 150 (36.5\%), 8 (1.9\%), 4 (1.0\%), and 2 (0.5\%) respectively. Thus, the scavengers in the area are mainly holders of FSLC, and SSCE/GCE because both of them contributed $83.2 \%$ or 342 responses. This differs from the findings of Nzeadibe (2009) in Nsukka region with informal education contributing $88.0 \%$ of waste pickers. A striking feature in this study is the involvement of $4 \mathrm{HND}$ and $2 \mathrm{~B}$. Sc. holders in scavenging jobs in the area. This is clear evidence of rampant unemployment and a show that higher education is not in pari passu with employment in the country. However, the few graduates involved in the job are as a result of low income generation and the fact that it is frequently looked down upon as a job for the less privileged. So, notwithstanding the high unemployment rate among graduates, the lack of dignity for the scavengers makes graduates to prefer sitting idle to engaging in waste picking. This is not the case for scavengers in Durban, United Kingdom where Dias and Samson (2016) discovered that the use of machines that separate wastes at their sources (such as magnetic field generating electrical machines that collect metals) have so dignified scavenging and made it easier that those with advanced knowledge are required to operate and maintain the machines.

The marital status of scavengers shows that majority are singles that constitute $64.4 \%$ (265) of the responses. This is followed by widowed with 73 responses $(17.8 \%)$, divorced $(46,11.2 \%)$, and scavengers who are married obtained only 27 responses that represent $6.6 \%$.

\section{USEFUL WASTE MATERIALS COLLECTED AT NSUKKA URBAN AREA}

Table 1 shows the types and proportions of waste materials collected in the study area. It revealed that the main waste materials collected for reuse are: metal materials (iron buckets, iron rods, zinc and aluminum, tin cans, iron parts of machines, motor wheels and iron parts of domestic utensils and home appliances); glass materials such as glass bottles, glass plates, cups and jugs, broken glass windows, beer and wine bottles, glass tables and room dividers made of glass materials; and plastic materials especially buckets, old tyres, bottles, chairs and tables. Others are paper materials of empty cartons, news papers, printed papers, old text books and other published materials, wrapping papers; and Food wastes (leftovers in homes, restaurants, hotels, and at ceremonies, spoilt vegetables and friuts). 
Table 1: Types of waste materials collected at Nsukka urban area.

\begin{tabular}{|c|c|c|c|c|c|c|c|c|}
\hline S/N & $\begin{array}{c}\text { Waste } \\
\text { material }\end{array}$ & $\begin{array}{c}\text { Ihe/Owerre } \\
(\%)\end{array}$ & $\begin{array}{c}\text { Mkpunano } \\
(\%)\end{array}$ & Nru (\%) & $\begin{array}{c}\text { Obukpa } \\
(\%)\end{array}$ & Total & $\begin{array}{c}\text { Percentage } \\
(\%)\end{array}$ & Rank \\
\hline 1 & Metals & $79(47.9)$ & $51(62.2)$ & $49(59.8)$ & $45(54.9)$ & 224 & 54.5 & $1^{\text {st }}$ \\
\hline 2 & Glasses & $40(24.2)$ & $18(22.0)$ & $20(24.4)$ & $20(24.4)$ & 98 & 23.8 & $2^{\text {nd }}$ \\
\hline 3 & Plastics & $18(10.9)$ & $7(8.5)$ & $8(9.8)$ & $10(12.2)$ & 43 & 10.5 & $3^{\text {rd }}$ \\
\hline 4 & Papers & $15(9.1)$ & $4(4.9)$ & $5(6.1)$ & $4(4.9)$ & 28 & 6.8 & $4^{\text {th }}$ \\
\hline 5 & Foods & $13(7.9)$ & $2(2.4)$ & - & $3(3.7)$ & 18 & 4.4 & $5^{\text {th }}$ \\
\hline Total & & $165(100)$ & $82(100)$ & $82(100)$ & $82(100)$ & 411 & 100 & \\
\hline
\end{tabular}

Source: Fieldwork, 2018.

The responses on these collected waste materials vary according to each of the administrative units in the area as found on Table 1 . At Ihe/Owerre, it is metal materials that occupy the $1^{\text {st }}$ position with response score of 79 or $47.9 \%$, while in the rear position of $5^{\text {th }}$ is waste food materials with 13 responses that represent 7.9\%. The response scores of other collected waste materials are shown on Table 1. Similarly, it is metal materials and waste food materials that are found in $1^{\text {st }}$ and last $\left(5^{\text {th }}\right)$ positions respectively in the other administrative units of Mkpunano, Nru, and Obukpa. This result is in consonance with the estimate of the Environmental Protection Agency (EPA) (2008) that metals are the highest waste materials recovered for recycling, accounting for $46.6 \%$ of globally recyclable wastes. The reason for this trend in Nsukka urban area is because metal materials are more abundant and command a higher price during sales. It is observed that at Nru administrative unit, none of the scavengers was able to collect waste food materials (Table 1). Also, the result on Table 1 indicates that at varying rates the same ranks are obtained by each of glass, plastic, paper, and food materials in the four administrative units in the study area.

From these, it is clear that metal materials are the most important waste materials collected by the scavengers at Nsukka urban area with response score of 224 (54.5\%) out of 411 respondents. Glass materials are in the $2^{\text {nd }}$ position and obtained score of 98 responses that is equivalent to $23.8 \%$ of the total responses in the area. In the $3^{\text {rd }}$ position are plastics with 43 responses or $10.5 \%$. With score of 28 responses and $6.8 \%$, paper materials obtained $4^{\text {th }}$ in rank; and found in the rear position of $5^{\text {th }}$ is waste food materials that obtained score of 18 $(4.4 \%)$ out of 411 responses (Table 1). For clearer visualization, the results on Table 1 are further illustrated on Fig. 3 which shows the size of the response scores and percentage of the responses on the useful waste materials obtained at Nsukka urban area.

\section{SPATIAL DISTRIBUTION OF USEFUL WASTE MATERIALS COLLECTED IN NSUKKA URBAN AREA.}

In order to determine the spatial distribution of useful waste materials collected in the area, KrusKal-Wallis statistical technique was applied on the response scores and their ranks in each of the administrative units in Nsukka Urban area (Tables 2). On a close look at Table 2, some materials clustered on some ranks by their possession of the same sizes of responses in some of the administrative units. Example, glass materials at Nru clustered on $6^{\text {th }}$ rank with the same glass materials at Obukpa. 
Table 2: Combined ranks of useful waste materials collected in Nsukka urban area.

\begin{tabular}{|c|c|c|c|c|}
\hline S/N & Waste Type & Responses & Rank & Admin. Unit \\
\hline 1 & 04 (plastics) & 18 & 7 & Ihe/Owerre \\
\hline 2 & 02 (metals) & 79 & 1 & " \\
\hline 3 & 01 (glasses) & 40 & 5 & " \\
\hline 4 & 03 (foods) & 13 & 10 & " \\
\hline 5 & 05 (papers) & 15 & 9 & Mkpunano \\
\hline 6 & 01 & 18 & 7 & " \\
\hline 7 & 04 & 7 & 13 & " \\
\hline 8 & 02 & 51 & 2 & " \\
\hline 9 & 03 & 4 & 15 & $"$ \\
\hline 10 & 05 & 2 & 18 & $"$ \\
\hline 11 & 02 & 49 & 3 & " \\
\hline 12 & 01 & 20 & 6 & " \\
\hline 13 & 03 & 5 & 14 & " \\
\hline 14 & 04 & 8 & 12 & 17 \\
\hline 15 & 03 & 3 & 17 & Obukpa \\
\hline 16 & 05 & 4 & 15 & " \\
\hline 17 & 04 & 10 & 11 & " \\
\hline 18 & 01 & 20 & 6 & " \\
\hline 19 & 02 & 45 & 4 & " \\
\hline
\end{tabular}

Source: Fieldwork, 2018.

Also, waste food materials at Mkpunano unit clustered on $15^{\text {th }}$ position with waste paper materials at Obukpa. Other useful waste materials that clustered on other ranks are found on Table 2.

The rank scores (Table 2) were used to calculate Ri (rank summation for each of the administrative units) and ni (number of observations) found on Table 3. At Ihe/Owerre, the useful waste materials, 01 ranked $5^{\text {th }}, 02$ ranked $1^{\text {st }}, 03$ is found in the $10^{\text {th }}$ position, 04 is on the $7^{\text {th }}$ position, and 05 occupies the $9^{\text {th }}$ position. These ranks gave the total rank scores of 32 (Table 3). The rank scores, $\sum \mathrm{Ri},\left(\sum \mathrm{Ri}\right)^{2}$, $\mathrm{Ni}$, and $(\mathrm{Ri})^{2} / \mathrm{ni}$ in the other administrative units in the study area are as shown on Table 3 .

Table 3: Rank of the responses on the useful waste materials in Nsukka urban area.

\begin{tabular}{|c|l|c|c|c|c|c|c|c|c|c|}
\hline S/N & Admin. Units & 01 & 02 & 03 & 04 & 05 & $\sum \mathrm{Ri}$ & $\left(\sum \mathrm{Ri}\right)^{2}$ & $\mathrm{Ni}$ & $(\mathrm{Ri})^{2} / \mathrm{ni}$ \\
\hline 1 & Ihe/Owerre & 5 & 1 & 10 & 7 & 9 & 32 & 1024 & 5 & 205 \\
\hline 2 & Mpkunano & 7 & 2 & 15 & 13 & 18 & 55 & 3025 & 5 & 605 \\
\hline 3 & Nru & 6 & 3 & 14 & 12 & - & 35 & 1225 & 4 & 306 \\
\hline 4 & Obukpa & 6 & 4 & 17 & 11 & 15 & 53 & 2809 & 5 & 562 \\
\hline $\mathbf{5}$ & Total & & & & & & 175 & 8083 & 19 & 425 \\
\hline
\end{tabular}

Source: Fieldwork, 2018.

To determine the level of variations in the spatial distributions of the types of useful waste materials in the area, the data on Table 8 are applied on the Kruskal-Wallis statistics of;

$$
H=\frac{12}{n(n+1)} \sum_{i=1}^{k} \frac{R_{i}^{2}}{n_{i}}-3(n+1)
$$

Where $\mathrm{n}=19$, and $\mathrm{k}=$ degree of freedom, and $(\mathrm{Ri})^{2} / \mathrm{ni}=425$

$$
H=\frac{12}{19(19+1)}[425]-3(19+1)
$$




$$
\begin{aligned}
\mathrm{H} & =\frac{12}{(361+19)}[425]-(57+3) \\
\mathrm{H} & =\frac{12}{380}[425]-60 \\
\mathrm{H} & =\frac{5100}{380}-60 \\
\mathrm{H} & =13.421-60
\end{aligned}
$$

Therefore, $\mathrm{H}=-46.579$

Due to the existence of clusters at the level of ranking of the responses which have the tendency to diminish the value of $\mathrm{H}$, there is the need to remove the effect of clusters on the value of $\mathrm{H}$. In order to do this, the value of $\mathrm{H}$ is divided by the total number of clusters $\left(\sum \mathrm{T}\right)$ and the total number of observations made (n). This implies that $\mathrm{H}$ will be adjusted using the formular;

$\mathrm{H}$ adjusted $=\mathrm{H} / \sum \mathrm{T} / \mathrm{n}\left(\mathrm{n}^{2}-1\right)$, where $\mathrm{H}=-46.579, \mathrm{n}=19, \sum \mathrm{T}=$ summation of rank groups ie $6+6+7+7+18+18=62$

$$
\begin{aligned}
\mathrm{H} \text { adjusted } & =-46.579 / 62 / 19\left(19^{2}-1\right) \\
& =-46.579 / 62 / 6859-19 \\
& =-46.579 / 1-0.019 \\
& =-46.579 / 0.981 \\
& =-47.481
\end{aligned}
$$

Therefore, $\mathrm{H}$ adjusted $=-47.481$. Degree of freedom $=\mathrm{k}-1$, where $\mathrm{K}$ is the number of administrative units $=4$. Thus, $4-1=3$. Critical value under 0.5 level of significance $=7.82$. In this sense, null hypothesis is accepted because the tabulated critical value of 7.82 is greater than the calculated value of - 47.481. Since, calculated value of H (-47.481) is less than the

\begin{tabular}{|c|c|c|c|c|c|c|c|c|c|}
\hline \multirow{2}{*}{$\mathrm{S} / \mathrm{N}$} & \multirow{2}{*}{ Admin. unit } & \multicolumn{5}{|c|}{ Collected waste materials } & \multirow[t]{2}{*}{ Total } & \multirow{2}{*}{$\begin{array}{c}\text { Percent. } \\
(\%)\end{array}$} & \multirow{2}{*}{$\begin{array}{c}\text { Ran } \\
\mathrm{k}\end{array}$} \\
\hline & & 01 & 02 & 03 & 04 & 05 & & & \\
\hline 1 & Ihe/Owerre & $5(14)$ & 1(18) & $10(9)$ & $7(12)$ & $9(10)$ & 352 & 28.7 & $1^{\text {st }}$ \\
\hline 2 & Mpkunano & $7(12)$ & $2(17)$ & $15(4)$ & $13(6)$ & $18(1)$ & 274 & 22.4 & $4^{\text {th }}$ \\
\hline 3 & Nru & $6(13)$ & $3(16)$ & $14(5)$ & $12(7)$ & - & 280 & 22.8 & $3^{\text {rd }}$ \\
\hline 4 & Obukpa & $6(13)$ & $4(15)$ & $17(2)$ & $11(8)$ & $15(4)$ & 320 & 26.1 & $2^{\text {nd }}$ \\
\hline Total & & $\begin{array}{c}310 \\
(25.3 \%) \\
\left(2^{\text {nd }}\right)\end{array}$ & $\begin{array}{c}160 \\
(13.1 \%) \\
\left(5^{\text {th }}\right)\end{array}$ & $\begin{array}{c}254 \\
(20.7 \%) \\
\left(3^{\mathrm{rd}}\right)\end{array}$ & $\begin{array}{c}334 \\
(27.2) \\
\left(1^{\mathrm{st}}\right)\end{array}$ & $\begin{array}{c}168 \\
(13.7 \%) \\
\left(4^{\text {th }}\right)\end{array}$ & 1226 & 100.0 & \\
\hline
\end{tabular}
tabulated critical value of $\mathrm{H}$ adjusted (7.82), the implication of this is that there are substantial similarities in the types of waste materials collected among the four administrative units in Nsukka Urban Area.

To statistically identify the most important waste materials and administrative unit in which the waste materials occur most, the rank of the materials in all the administrative units were scored on a scale of $1-18$ in which scale 18 is for the $1^{\text {st }}$ position and scale 1 stood for the rear and $18^{\text {th }}$ position. The computation result is found on Table 4, which indicates that with the cumulative rank score of 352 (28.7\%), Ihe/Owerre took the $1^{\text {st }}$ position, and Mkpunano obtained the rear position of $4^{\text {th }}$ with total rank score of 274 that represent $22.4 \%$.

Table 4: Administrative units and collected waste materials in the area

Source: fieldwork, 2018 
This is an indication that the waste materials occur most at Ihe/Owerre and least at Mkpunano. Table 4 shows the rank scores and positions of other administrative units in the area. Among the collected waste materials, 04 (plastics) obtained the highest total rank scores $(334,27.2 \%)$ to be in the $1^{\text {st }}$ position, and 02 (metals) that is found in the $5^{\text {th }}$ and rear position scored 160 or 13.1\%. The results of the other waste materials collected are as contained on Table 4.

USES OF THE USEFUL WASTE MATERIALS COLLECTED AT NSUKKA URBAN AREA.

The useful waste materials from the streams of wastes in the study area are mainly sold as source of income and for domestic/personal uses. On the whole, 321 respondents that are equivalent of $78.1 \%$ sale the collected waste materials as source of income, while 90 respondents or $21.9 \%$ use and convert the materials for domestic or personal uses (Table 5). As income generation, collected materials are most often sold to junk shops owners who at times squeeze, package, and move them to recycling plants at mainly Port Harcourt (PH) and or Lagos. Other materials especially plastics are rewashed and sold to domestic plants that use them as raw materials in the production of shopping bags, and cellophane materials.

Also, waste food materials are assembled and used as foods for farm animals. Papers especially thick papers are used as ceiling boards in the shops as well as in packaging domestic/house properties depending on their sizes. Again, iron and some plastic containers are very important in storage of water and palm oil, while milk containers area washed after removal of their lids and used in cooking of ground-pear (okpa) and moi-moi as well as in sales of grains like maize, beans, fio-fio, okpa, melon, ogbono, etc.

Table 5: Uses of collected waste materials in Nsukka urban area

\begin{tabular}{|c|c|c|c|c|c|c|c|c|}
\hline $\mathrm{S} / \mathrm{N}$ & \multirow{2}{*}{$\begin{array}{l}\text { Use of collected } \\
\text { material }\end{array}$} & \multicolumn{4}{|c|}{ Administrative units } & Total & Percent.(\%) & Rank \\
\hline & & Obupka & Nru & Mpunano & Ihe/Owerre & & & \\
\hline 1 & $\begin{array}{l}\text { Domestic/Personal } \\
\text { use }\end{array}$ & 16 & 11 & 20 & 43 & 90 & 21.9 & $1^{\text {st }}$ \\
\hline 2 & Source of income & 67 & 72 & 62 & 120 & 321 & 78.1 & $2^{\text {nd }}$ \\
\hline & Total & 100 & 100 & 100 & 200 & 411 & 100.0 & \\
\hline
\end{tabular}

Source: Fieldwork, 2018.

Also, found on Table 5 is the spatial variation on the number of respondents on the use of the collected waste materials. As source of income they are more at Ihe/Owerre, and least at Mkpunano, and for domestic/personal uses, the highest number is still found at Ihe/Owerre, while Nru has the least number of respondents involved in the domestic/personal use of the waste materials.

\section{AVERAGE MONTHLY INCOME OF SCAVENGERS}

The results on Table 6 show that average monthly income of scavengers from the useful waste materials collected ranges from below $\$ 2,000.00$ to above $\$ 20,000.00$. The first position is occupied by the average of $\$ 10,001.00$ - $\$ 20,000.00$ with response scores of 161 (39.2\%).

Table 6: Average monthly income of scavengers in the study area.

\begin{tabular}{|c|l|c|c|c|}
\hline S/N & Range (N) & Frequency & Percentage (\%) & Rank \\
\hline 1 & Below 2,000.00 & 45 & 11.0 & $4^{\text {th }}$ \\
\hline 2 & $2,001.00-5,000.00$ & 63 & 15.4 & $3^{\text {rd }}$ \\
\hline 3 & $5,001.00-10,000.00$ & 114 & 27.8 & $2^{\text {nd }}$ \\
\hline 4 & $10,001.00-20,000.00$ & 161 & 39.2 & $1^{\text {st }}$ \\
\hline 5 & Above 20,000.00 & 28 & 6.6 & $5^{\text {th }}$ \\
\hline 6 & Total & 411 & 100.0 & \\
\hline
\end{tabular}

Source: Fieldwork, 2018. 
In the $2^{\text {nd }}$ position is the range of $\$ 5,001.00$ - $\$ 10,000.00$ with $27.8 \%$ or 114 responses, while the rear position of $5^{\text {th }}$ is obtained by average range of above $\$ 20,000.00$. Others are shown on Table 6. These results are further illustrated on Fig. 4 for clearer visualization, and in which range of $\$ 10,000.00$ - $\$ 20,000.00$ stands out clearly as the most important, while above $\mathrm{N} 20,000.00$ is the least in occurrence.

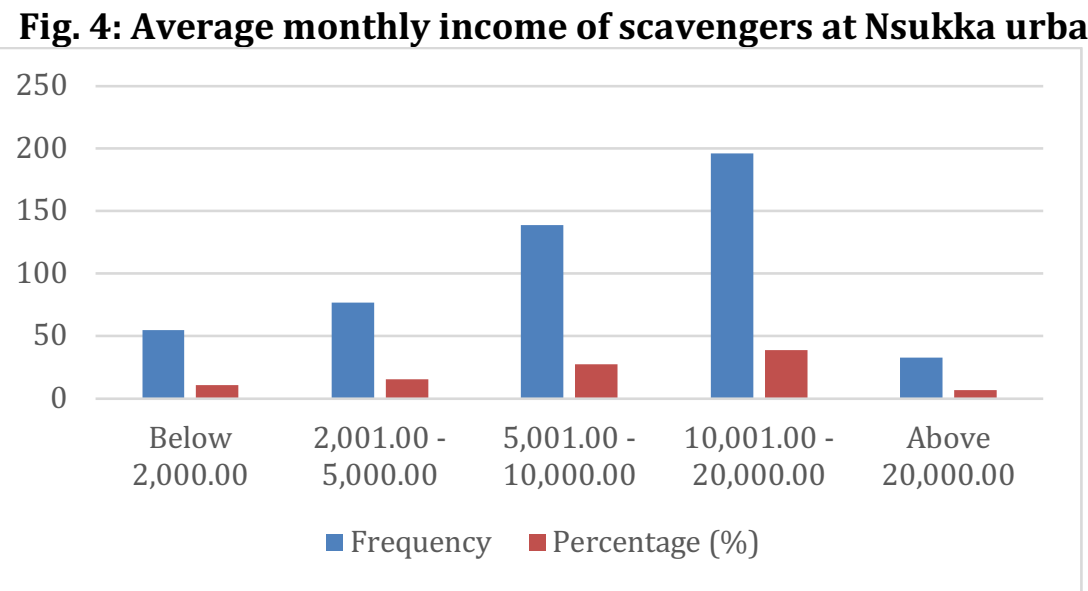

Source: Fieldwork, 2018.

This result is in accordance with that of Chukwu (2016) who carried out similar study in Enugu North Local Government Area of Nigeria, and found that those earning between $\$ 10,000.00$ and $\$ 20,000.00$ are highest (38.9\%). But, it is in discordant with the research findings of Dias and Samson (2016) in Durban, United Kingdom, where average monthly income earnings of scavengers are as high as $€ 150.00(\$ 69,075.00)$ per person and per month.

\section{A compare of minimum wage in Enugu state and income from scavenging in Nsukka urban}

In Nigeria, since 2010, the minimum wage per month is $\$ 18,000.00$, but in some states, an example of Enugu state, it is not implemented. It varies according to ranks, for levels 1-7 it is $\mathrm{N} 18,000.00$ and about $\$ 8,000.00$ per month for 8-16 level officers. From this, majority of waste pickers (67.0\%) whose monthly income ranges from $\$ 5,000.00-\$ 20,000.00$ per month in the area earn more than the civil servants in the state. In addition, these scavengers indulge in other income earning informal activities like farming, petty trading, artisans as even reported by Nzeadibe (2009) that $54.0 \%$ of the waste pickers in the area and the peripheries have alternative jobs.

\section{SUMMARY}

Recycling is an effective way of reducing the quantities of wastes found in our environment and in addition, helps to relieve the pressure mounted on fresh natural resources by providing alternative raw materials as well as income sources. This research focused on collection and analyses of data on the socio-economic features of scavengers, income levels, and importance of scavenging in Nsukka urban Area. This inquiry revealed that scavengers prefer sales of collected materials to personal/domestic uses. The sales generate incomes that range between N2,000.00 and $\mathbf{N} 20,000.00$ for the majority of the scavengers.

Furthermore, metal materials constitute the highest waste materials collected due to their availability and higher price. Classes of useful waste materials collected in the area are; metals, plastics, glasses, papers, and foods. More so, the demographics of scavengers in Nsukka urban area exhibit a predominance of males and youths. The huge energy requirements of the job 
have been given as the major reason for this. This study showed that most of the informal sector scavengers are just those who hold FSLC and SSCE/GCE (83.2\%), and very few are found in other levels of education like non-formal, OND, HND B Sc/ B A (16.8\%). Respondents frequently blamed the derogatory nature of the scavenging business as the force that drives graduates away. Notwithstanding, the scavenging activities have contributed significantly to the economic wellbeing of the scavengers through the provision of employment, generation of incomes, and reduction in the quantity/amount of waste material available in Nsukka urban area.

\section{RECOMMENDATION}

From the results of this research, it is recommended that scavengers can boost their economic powers by forming cooperatives that will enable them lend a stronger voice during price determination. The scavenging business in Nsukka urban area is still largely hampered by the scarcity of recycling companies to absorb collected waste materials. It is recommended that government as well as private investors should all work to establish more of such companies in order to deal with huge amount of useful waste materials collected in the area. This will inevitably create higher demand for collected waste materials, thus, improving their prices and subsequently, raising income and standard of living of scavengers in Nsukka urban area. There is also the need to organize campaign that will enforce and encourage separation of waste materials according to types/classes in the study area.

\section{CONCLUSION.}

Scavenging represents an adaptive response to the growing rates of unemployment and poverty among Nsukka citizens. But this need not be the case as scavenging could be much more positive, if given the right kind of attention by those in positions of authority. Scavenging in Nsukka urban area has contributed to the development of the informal sector of the economy by providing though at minimal scale employment opportunities that generate income and provide useful waste materials for both domestic and personal uses. It has also facilitated the supply of cheap and secondary raw materials for industries, thus, reducing demand for natural resources in the area. As with any other human activity, formal or informal, scavenging in the area exhibits variations in the gender, age, educational, and marital status, types of materials collected as well as income levels.

There are challenges that scavengers irrespective of administrative units face. The most glaring one is the undignified nature of the activities involved, while others include the health hazards associated with this job, low income, and exploitation by junk shop owners especially during price bargaining for the collected and useful waste materials.

\section{References}

Agu, K. (2010): “Land use and solid waste generation in Enugu State”, the Environmentalist, 18 (2), 67-75.

Amah, N.N. (2006): The urban trend in Nsukka. Unpublished Master's Thesis, Department of Geography, University of Nigeria, Nsukka (UNN).

Asim, J.J. (2012): Waste management techniques. St. Lois, Markfell Books.

Birkberck, R.B. (2000): “Waste disposal." The Encyclopedia Americana International Edition, Erolier Incorporated Publishing, 28, 424.

Chukwu, G.N. (2016): Waste recycling as a means of livelihood in the informal sector of Enugu North Local Government Area; unpublished B.Sc. research report, Department of Geography and Meteorology, ESUT.

Cooper, S. (2011). “The state of our environment.” Encyclopedia Britannica. 73- 89.

Deuskar, C. (2015): What does "urban" mean? The World Bank Group. 
Ogbu, S. O., Ajadike, J. C., \& Ugwu, H. N. (2019). Waste Recycling, An Example Of Refuse Collecting As A Means Of Livelihood In The Informal Sector Of Nsukka Urban Area, Enugu State, Nigeria. Archives of Business Research, 7(11), 50-66.

Dias, S.M. and Samson, M. (2016): “Waste pickers”.Journal of Informal Economy Sector Report, WIEGO. Nepal. 3, 13. Diaz, U.N. (2008): Third world pollution; The national problem of solid waste disposal: New York, Praegen publisher.

Ekwueme, I. and Achikanu, C. (2002): "Solid waste management in the city of Enugu. Paper presented at the Nigerian Society of Engineers, Enugu branch on 23rd June, Enugu, 2.

Environmental Protection Agency (EPA) (2008): The Nigerian Environment 2008-2010. "New Shelter Belt," EPA, Lagos.

Espinoza, D. (2014): “the ocean also feels." National Geographic Publication, 11-12.

Jersey, A. H. (2018): Introduction to Environmental Technology. New Orleans, lceberg publishing company.

Joanna, C. (2010): Oxford Advanced Learners Dictionary, London press, London.

Joanna, C. (2008): Oxford Advanced Learners Dictionary, London press, London.

Loan, M. (2002): Environmental sciences; an introduction. California, Wordsworth Publishing Company.

Madu, I. (2004): “Landscape architecture”. A paper presented at the $6^{\text {th }}$ annual general meeting of Nigerian Society of Estate Surveyors. I5th, April. 51- 63.

Madu, N. (2004): Poverty and basic needs series; institutional problem in management of Nigerian urban environment. Ibadan, University press.

McGrew, K. and More, S. (2000): “waste disposal” World Book Encyclopedia, Chicago, World Book Inc.

Medina, M. (2007): The world's scavengers; Salvaging for sustainable consumption and production. New York, Altamira press.

Mustapher, M. (2011): The youth and waste scavenging in Nigeria: Implication for socioeconomic and health hazards. Ibadan, Ibadan Publishers.

Nigeria Meteorological Agency (NMA) (2014): “Enugu state.” Seasonal rainfall prediction, Abuja.

Nzeadibe T. C. (2009): "Development drivers of waste recycling in Nsukka urban area, Southeastern Nigeria." Theoretical and Empirical Researches in Urban Management 4(3(12)), 137-150 •

Odocha, J. N. (2002): "Waste generation and management in a depressed economy." a lecture to students of law and environmental facilities, UNEC. Enugu.

Paulson, B.L. (2017): The recycling alternative. Sidney, Neon Loft Books.

Schreiber, M. (2018): “Aftermath of Saturday's earthquake.” This Week, in USA Today, Washington. 17th February.

Seligoretal, T. (2002): "Informal income opportunities and urban employment in Ghana" Journal of modern African studies, Accra, 11 (91), 61-89.

Sidwell, I. O. (2016): Economics of Our Environment. Detroit, Hillside press.

Sigh, S. (2015): Geography. New Delhi, McGraw Hills Publishing.

Smithsonia, (2016): “The menace of waste" Smithsonian annual magazine. Washington, 154.

Sociology Group (2017): What is the Meaning of Urban Community

Standing, D. F. (2000): “How to manage your trash.” Encyclopedia Americana, 157.

Ugwuishiwu, B. O. Nwodo, J. C. and Echiegu, E. A. (2016):"Municipal Solid Waste Characterization in Nsukka Urban in South East Nigeria." Transylvanian Review XXIV(7),808 - 815 •

UN Habitat (2010): The challenge of slums; Global report on human settlements. London, Earthscan.

United States Department of Agriculture (USDA) (2015): “The grey water alternative”. Journal of Agricultural Research, Kansa,. 11 (7), 43.

World Health Organisation (WHO) (2013): “The dangers of informal sector waste picking”. Journal of Environmental Health, Geneva, 61 (78), 111. 